\title{
Comparative studies of the spruce tree stand in the Tatrzański National Park
}

\author{
T. Staszewski ${ }^{1}$, A. K. Uziębło ${ }^{2}$, P. Kubiesa ${ }^{1}$, W. Łukasik $^{1}$
}

Tomasz Staszewski, Piotr Kubiesa, Włodzimierz Eukasik, Instytut Ekologii Terenów Uprzemysłowionych, Kossutha 6, 40-833 Katowice, e-mail: stasz@ietu.katowice.pl

Aldona Katarzyna Uziębło, Uniwersytet Ślaski, Wydział Biologii i Ochrony Środowiska, Jagiellonska 28, 40-032 Katowice

Abstract: Staszewski, T., Uziębło, A. K., Kubiesa, P., Łukasik, W. 2012: Comparative studies of the spruce tree stand in the Tatrzański National Park. - Beskydy, 5 (1):27-36

The paper presents the results of an investigation carried out at a permanent plot in spruce stand of the Tatrzański National Park in the years 1998-2006. Concentrations of phytotoxic gases in the air together with the load of acidifying compounds reaching the forest soil were characterized. The forest ecosystem response was evaluated by analysing the chemistry of the needles, changes in health status of trees and floral composition. Neither exceedances of the critical $\mathrm{SO}_{2}$ and $\mathrm{NO}_{2}$ concentration levels in the air nor the critical load of acidity were found. Only ozone concentration level was recognised as a potential threat to the trees. Heavy metal concentrations in spruce needles represented levels concerned as non-hazardous for the health status of the tree stand. The use of the spruce needles as a cumulative bioindicator showed the presence of PAHs with carcinogenic properties in the air. The investigated spruce stand belongs to the slightly damaged class, however in the period of 1998-2004 a deterioration of the spruce trees condition was observed expressed by a diminishing number of health trees. A comparative investigation carried out in the years 2001 and 2006 proved stability of the floral composition at the permanent plot.

Key words: spruce stand, phytotoxic gases, critical load, health status of trees, floral characteristics

\section{Introduction}

In the second half of the $20^{\text {th }}$ century forest ecosystems were exposed to a strong anthropopression due to poorly controlled emissions of industrial pollutants. High level of acidic gases, particulate matter, and heavy metals deposition to ecosystems caused that Poland has been known as one of the most polluted countries in Europe with a high level of forest injury (Europe's Environment 1995).

Enforcement of the Environmental Protection Act in Poland in early nineties based on legislative and economic instruments resulted in an improvement of the air status (GUS 2006).
In this context it seemed relevant to determine the response of the forest ecosystems to these measures by performing integrated monitoring investigations. The aim of the integrated monitoring in the forest is to determine and predict the state of the ecosystem and its changes in a long-term perspective, with respect to the regional variation and impact of air pollutants, including effects on biota.

This paper presents the results of a research on the health status changes of trees, floral characteristics and air pollution level, which have been observed at permanent plot located in the spruce forest in the Tatrzański National Park in the years 1998-2006. 


\section{Methods}

In 1998 a permanent plot ( 50 x 50m) was established on the slope of the Nosal Mountain $\left(46^{\circ} 25^{`} 00^{\prime} \mathrm{N}, 20^{\circ} 21^{`} 00^{\prime} \mathrm{E}\right)$ ) at the height of $970 \mathrm{~m}$ asl in 120 year old spruce stand according to (Manual of methodologies... 1994).

\section{Air pollution}

In 1998-1999 and 2004-2005 measurements of $\mathrm{SO}_{2}, \mathrm{NO}_{2}$ and $\mathrm{O}_{3}$ concentration in the air were carried out on monthly basis using passive samplers (Gradko Ltd, Ogawa). Exposition filters were rinsed with distillated water. The $\mathrm{NO}_{2}$ concentration in the solution was determined by photocolorimetric method (Spekol 11 , Jena) and $\mathrm{O}_{3}$ and $\mathrm{SO}_{2}$ concentration by chromatographic method (Dionex DX 100, Ion-Pac AS4A column). In the same periods throughfall was collected every month. Ion chromatograhic method was used to determine $\mathrm{SO}_{4}^{2-}$ and $\mathrm{NO}_{3}$ concentrations in water (Dionex DX100, IonPac AS4A column). Concentration of $\mathrm{NH}_{4}{ }^{+}$in water samples was determined using the Nessler method.

\section{Sampling and analysis of needles}

Needles were sampled in standardized way from the 7th whorl shoots of six trees. The averaged samples of current year needles were analyzed. The samples were divided into two parts. One part (10g of fresh weight) was taken to determine the amount of heavy metals contents deposited on the needle surface, the other part was used to determine heavy metals concentration in needles. The sampling was carried out in 2002. Next year, $40 \mathrm{~g}$ of current year needles were taken in the same way to determine PAH deposit.

After washing with chloroform for 15 s., the needles were dried to determine the dry weight. Dust was separated from wax solution by an underpressure filtration (Sartorius filters) (Cape et al. 1989). Filter papers with dust were mineralized with nitric acid in the MDS 2000 microvawe system. Contents of $\mathrm{Cd}$ and $\mathrm{Pb}$ were determined by a AAS method with graphite cuvette. Contents of $\mathrm{Cu}$ and $\mathrm{Zn}$ were determined by a ICP method with the ultrasonic nebulizer. The other part of the needles was ground and mineralized with nitric acid in the MDS 2000 microvawe system. Contents of $\mathrm{Cd}, \mathrm{Pb}, \mathrm{Cu}$ and $\mathrm{Zn}$ was determined as above.

For PAHs analysis $10 \mathrm{~g}$ of needles were dried at $30^{\circ} \mathrm{C}$ and ground. Organic compounds were extracted from plant material using dichloromethane. PAHs were separated on florosil and analysed by HPLC (BECKMAN liquid chromatograph) using a UV detector. Identification of the separated compounds was carried out by comparing their retention times with the values obtained from a mixture of the Supelco PAH - Mixture 610 - M (Wild, Jones 1991, 1992). Seventeen polycyclic aromatic hydrocarbons (PAHs) listed by the United States Environmental Protection Agency (US EPA) and the European Community as priority pollutants were analysed.

\section{Health status of trees}

In 1998 and 2004 the health status of trees was assessed according to the method of ICP-FOREST (1998). Determination of the spruce trees condition was based on the assessment of the crown defoliation and discoloration performed for 20 trees with an accuracy of $5 \%$ on each permanent plot. Defoliation and discoloration indices were calculated. Level of trees injury was determined from combination of defoliation and discoloration classes according to pattern given in Manual of methodologies ...(1994).

\section{Floral characteristics}

In 2001 and 2006, the plant communities at the permanent plot were described. One hundred phytosociological relevés were made in the quadrates of $25 \mathrm{~m}^{2}$ in size on the plot. The percentage cover of species in each layer of phytocenosis was estimated in the following scale: $1 \%, 5 \%, 10 \%, 20 \%, \ldots, 100 \%$. This scale seems to be more precise than the more commonly used Braun-Blanquet's scale.

In this study only vascular plant layers (tree stand, brushwood and herb) were analysed in detail. The moss layer was temporarily estimated including only dominant species. The list of species including contribution (frequency - percentage of squares with given species and range of percentage cover) of species in individual vegetation layers: A - tree, B - brushwood, C - herbs, D - mosses is presented. Nomenclature of species, was adopted after Mirek et al. (2002), of associations after Matuszkiewicz (2001), and of mosses after Ochyra et al. (2003).

\section{Results and discussion}

In both measurement periods the critical level of 20 and $30 \mu \mathrm{g} \mathrm{m}^{3}$ (UN-ECE 1998) for $\mathrm{SO}_{2}$ and $\mathrm{NO}_{2}$, as well as the Polish standards of these gases for national parks 15 and $20 \mu \mathrm{g} \mathrm{m}^{3}$ (Official Journal of Laws No. 87 item 796 of 2002), respectively were not exceeded. Maximal concentrations of $\mathrm{SO}_{2}$ were found in the winter-time, 
whereas such phenomenon was not observed for $\mathrm{NO}_{2}$ (Fig. 1, 2). A slight decrease in the mean annual concentrations of both gases was observed in 2004-2005 compared to the period of 1998-1999 (Fig. 1, 2).

The presented values of ozone concentration for the growing season can be compared to the ozone level of $60 \mu \mathrm{g} \mathrm{m}^{3}$ recommended by WHO as a permissible concentration for plants for this period (Jol i Kielland 1997). In 1999 and 2005 these values were exceeded in the Tatrzański National Park (Fig. 3). Other investigations carried out in the same period showed the exceedance of AOT40 permissible level in this area (Bytnerowicz et al. 2004, Godzik 2006).

The annual loads of sulphur and nitrogen reaching the forest soil did not change during the investigation period and maintained at the level of $16 \mathrm{~kg}$ and $15 \mathrm{~kg}$ for sulfur and nitrogen, respectively. The obtained results were used to assess the exceedance of the critical acidity loads at individual sites. The values of the critical loads in the grid of $1 \times 1 \mathrm{~km}$ were taken from (Mill et al. 2009). The presented data indicate that the critical load of acidity was not exceeded (Fig. 4).

Needles and their surface can be used as a cumulative indicator (Staszewski 2004). In this study spruce needles were used to determine PAHs and heavy metals deposit to forest.
If plant material (above-ground) contains PAHs it is considered as a result of atmospheric deposition (Jones et. al. 1989, 1992, Wild et al. 1992). Deposition of PAHs on foliage is a function of their concentration in the air (Riederer 1990). Hence, the leaves are a convenient passive sampler for monitoring concentration of PAHs in the air.

Table 1 shows the spectrum of PAHs found in the spruce needles in the Tatrzański National Park where 2, 3, and 4 rings prevail in a sum of $\mathrm{PAH}$ compounds. The carcinogenic PAHs make about $4 \%$ of total PAHs (Tab. 2).

It was stated that the amount of heavy metals (particularly cadmium and lead) in plants and on their surface in the forest exposed to air pollutants was determined mainly by wet and dry deposition (Heinrichs, Mayer 1980, Turner et al. 1985, Zőttl 1985, Szarek, Braniewski 1996).

The concentration of $\mathrm{Pb}$ in spruce needles was found to be at minimal and Cd at a slightly elevated level according to a five degree scale of Arndt et al. (1987). The concentrations of $\mathrm{Cu}$ and $\mathrm{Zn}$ found in the needles were in the range of their optimal values $-2-12 \mathrm{mg} / \mathrm{kg}$ d.w and 15-30 $\mathrm{mg} / \mathrm{kg}_{\text {d.w }}$, respectively (Kabata - Pendias, Pendias 1992) (Tab. 3).

Deposit of heavy metals accumulated on the needles surface contributes only in several

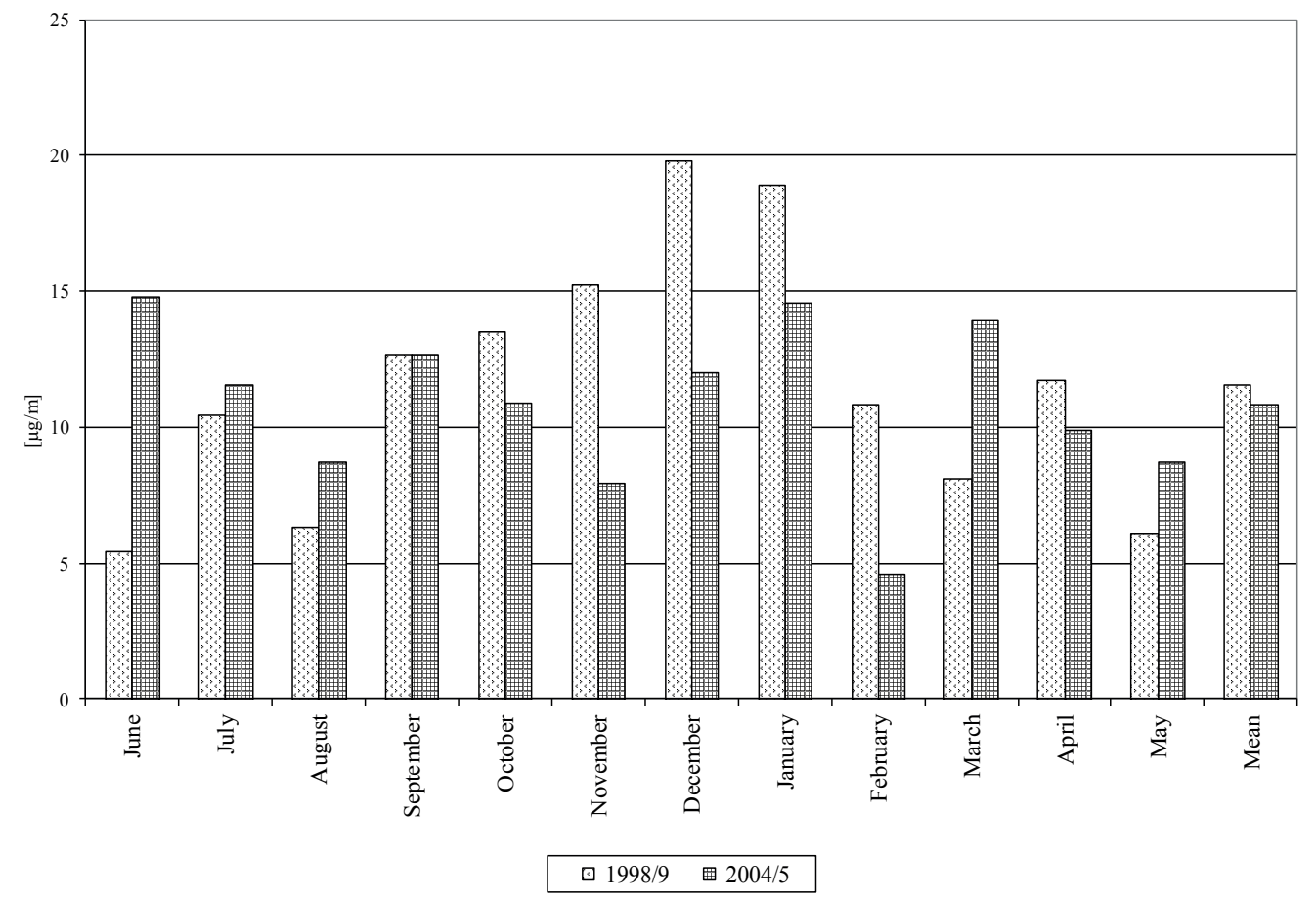

Fig. 1: Comparison of mean monthly and annual $\mathrm{SO}_{2}$ concentration for 1998/1999 and 2004/2005 in the Tatrzanski NP. 


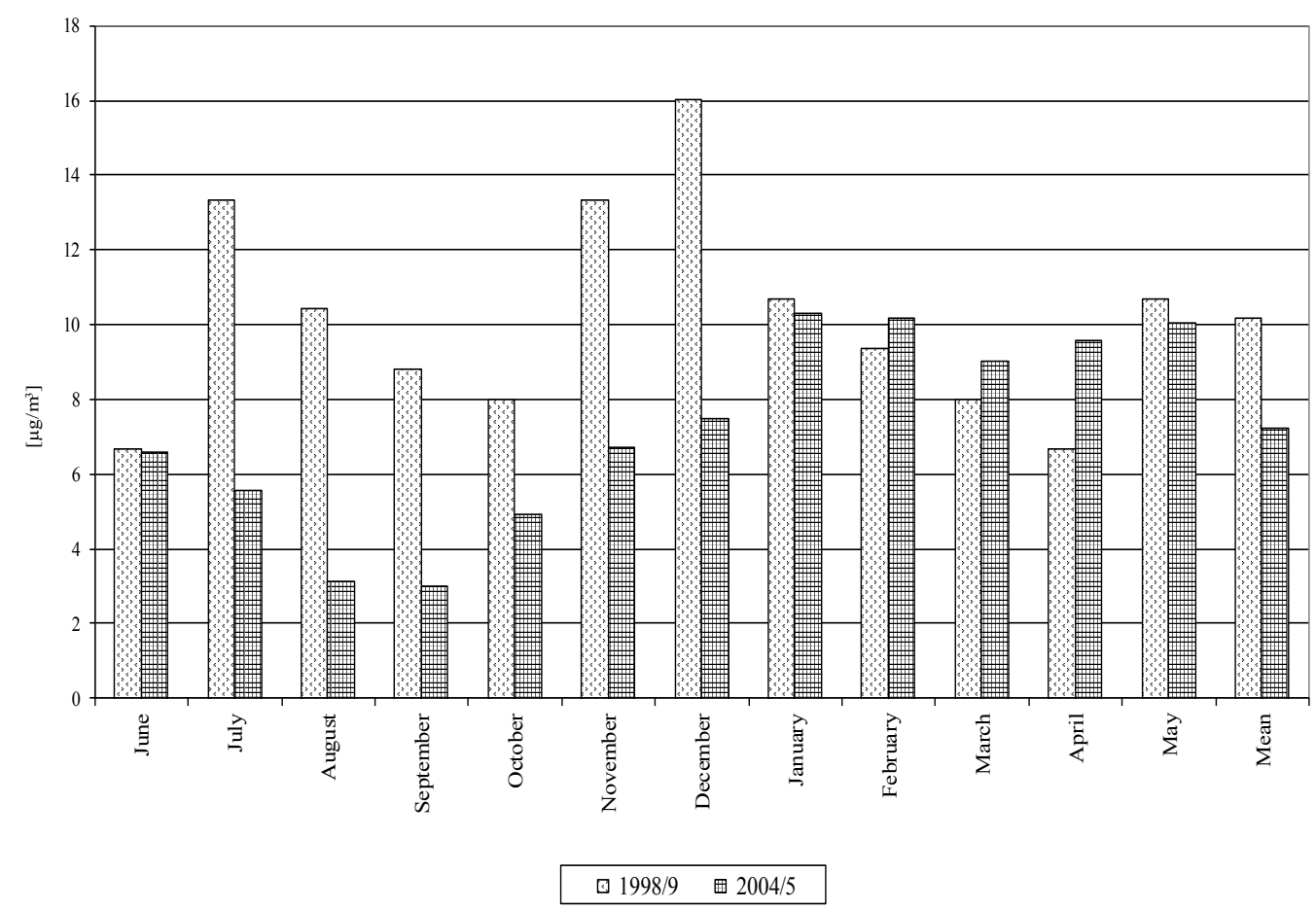

Fig. 2: Comparison of mean monthly and annual $\mathrm{NO}_{2}$ concentration for 1998-1999 and 2004-2005 in the Tatrzański NP.

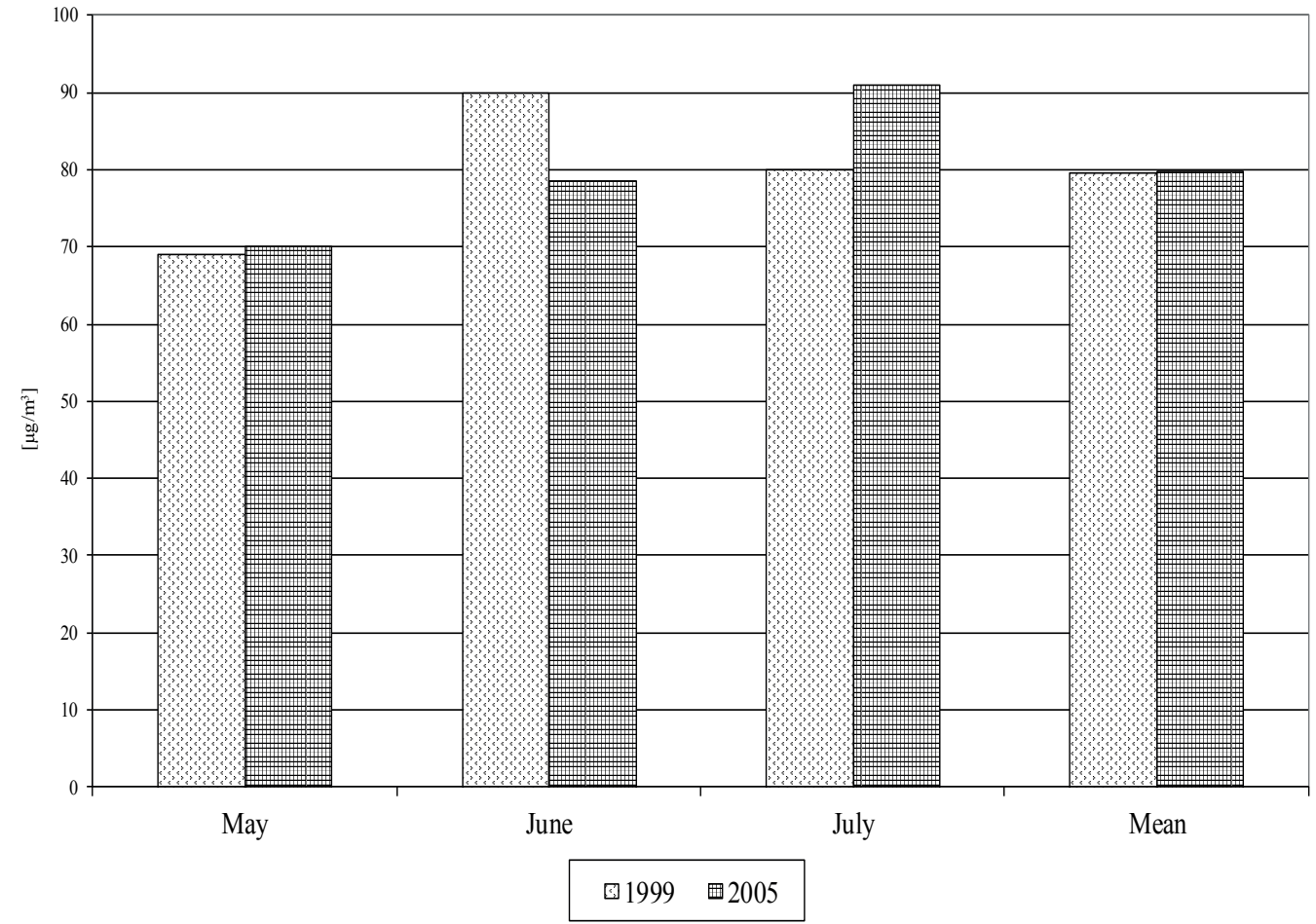

Fig. 3: Comparison of $\mathrm{O}_{3}$ concentration in growing season for 1999 and 2005 in the Tatrzanski NP. 


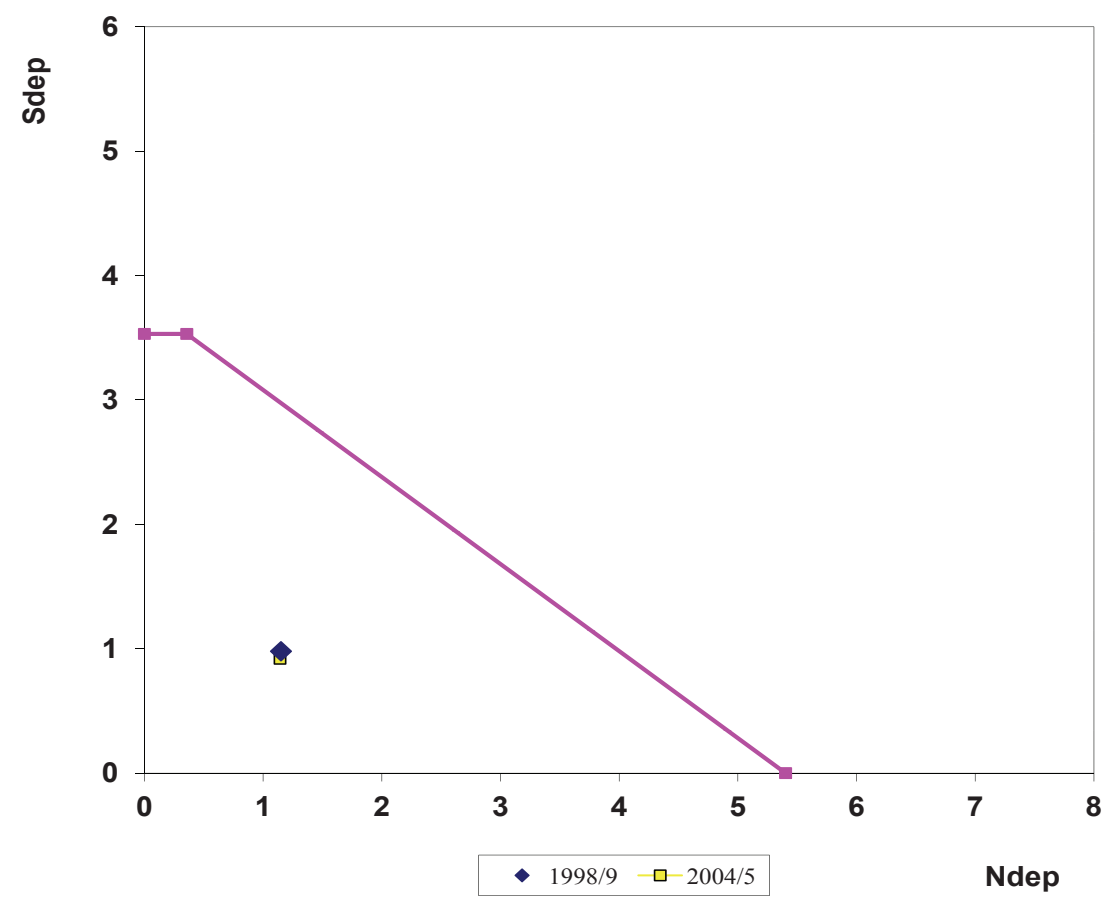

Fig. 4: Critical load of acidity for soil in the Tatrzański NP [kval hat year-1].

Tab. 1: Concentration of 17 PAHs including carcinogenic PAHs in spruce needles in the Tatrzański NP.

\begin{tabular}{|c|c|c|}
\hline РAH & $\begin{array}{l}\text { Amount of } \\
\text { rings }\end{array}$ & $\begin{array}{c}\text { Concentration of } \\
\text { PAHs } \\
{\left[\mu \mathrm{g} \mathrm{g}^{-1} \text { d.w. }\right]}\end{array}$ \\
\hline $\mathrm{Na}$ & 2 rings & 67.49 \\
\hline Acna & \multirow{4}{*}{3 rings } & 4.70 \\
\hline Fluo & & 0.00 \\
\hline Phen & & 88.70 \\
\hline Anth & & 0.00 \\
\hline Fluant & \multirow{4}{*}{4 rings } & 119.96 \\
\hline Pyr & & 8.96 \\
\hline Bzaan & & 2.31 \\
\hline Chry & & 3.31 \\
\hline Bep & \multirow{5}{*}{5 rings } & 5.26 \\
\hline Bzbfl & & 3.01 \\
\hline Bzkfl & & 1.05 \\
\hline Bap & & 0.92 \\
\hline Dibzan & & - \\
\hline Bzper & \multirow{2}{*}{6 rings } & - \\
\hline Ind & & - \\
\hline Cor & 7 rings & - \\
\hline \multicolumn{2}{|c|}{ Sum of 17 PAHs } & 305.68 \\
\hline \multicolumn{2}{|c|}{ Sum of carcinogenic PAHs } & 10.60 \\
\hline
\end{tabular}


Tab. 2: Percentage contribution of individual PAHs classes and carcinogenic compounds in 17 PAHs pool in spruce needles in the Tatrzański NP.

\begin{tabular}{|c|c|c|c|c|}
\hline \multicolumn{4}{|c|}{ Individual PAHs classes [\%] } & \multirow{2}{*}{$\begin{array}{l}\text { Contribution } \\
\text { of carcinogenic } \\
\text { compounds in pool } \\
\text { of } 17 \text { PAHs [\%] }\end{array}$} \\
\hline $2 \& 3$ rings & 4 rings & 5 rings & $6 \& 7$ rings & \\
\hline 52.64 & 44.02 & 3.35 & 0.00 & 3.47 \\
\hline
\end{tabular}

Tab. 3: Total concentration of heavy metals in spruce needles and on needles surface and their ratio in the Tatrzanski NP.

\begin{tabular}{lcccc}
\hline & $\mathbf{P b}$ & $\mathbf{C d}$ & $\mathbf{C u}$ & $\mathbf{Z n}$ \\
\cline { 2 - 5 } Total concentration $\left[\mathbf{m g ~ k g}^{-1}\right]$ & 0,65 & 0,11 & 4,84 & 25,93 \\
Surface concentration $\left[\mathbf{m g ~ k g}^{-1}\right]$ & 0,0482 & 0,0022 & 0,0964 & 0,0771 \\
Surface / total & 7,42 & 2 & 1,99 & 0,3 \\
\hline
\end{tabular}

Tab. 4: Contribution of trees to 10\% defoliation and discoloration classes and defoliation and discoloration indices in spruce stand of the Tatrzanski NP.

\begin{tabular}{|c|c|c|c|c|c|c|c|c|c|c|c|}
\hline \multirow{4}{*}{ Year } & \multicolumn{10}{|c|}{ Class Range } & \multirow{4}{*}{$\begin{array}{l}\text { Defoliation } \\
\text { index }\end{array}$} \\
\hline & 1 & 2 & 3 & 4 & 5 & 6 & 7 & 8 & 9 & 10 & \\
\hline & $0-10$ & 20.11 & $21-30$ & $31-40$ & $41-50$ & $51-60$ & $61-70$ & $71-80$ & $81-90$ & 91-100 & \\
\hline & $\%$ & $\%$ & $\%$ & $\%$ & $\%$ & $\%$ & $\%$ & $\%$ & $\%$ & $\%$ & \\
\hline \multicolumn{12}{|c|}{ Defoliation } \\
\hline 1998 & 30.0 & 60.0 & 10.0 & 0.0 & 0.0 & 0.0 & 0.0 & 0.0 & 0.0 & 0.0 & 1.80 \\
\hline 2004 & 10.0 & 65.0 & 25.0 & 0.0 & 0.0 & 0.0 & 0.0 & 0.0 & 0.0 & 0.0 & 2.20 \\
\hline \multicolumn{11}{|c|}{ Discoloration } & $\begin{array}{c}\text { Discoloration } \\
\text { index }\end{array}$ \\
\hline 1998 & 100 & 0.0 & 0.0 & 0.0 & 0.0 & 0.0 & 0.0 & 0.0 & 0.0 & 0.0 & 1.00 \\
\hline 2004 & 100 & 0.0 & 0.0 & 0.0 & 0.0 & 0.0 & 0.0 & 0.0 & 0.0 & 0.0 & 1.00 \\
\hline
\end{tabular}

Tab. 5: Contribution of trees to damage classes in spruce stand of the Tatrzański NP [\%].

\begin{tabular}{|c|c|c|c|c|c|c|}
\hline \multirow[b]{3}{*}{ Year } & \multicolumn{6}{|c|}{ Damage class } \\
\hline & 0 & 1 & 2 & 3 & & \\
\hline & $\begin{array}{l}\text { without } \\
\text { damage }\end{array}$ & warning & $\begin{array}{c}\text { slight and } \\
\text { moderate } \\
\text { damage }\end{array}$ & $\begin{array}{c}\text { high } \\
\text { damage }\end{array}$ & $\begin{array}{c}\text { classes } \\
2+3\end{array}$ & $\begin{array}{c}\text { classes } \\
1+2+3\end{array}$ \\
\hline 1998 & 30 & 70 & 0 & 0 & 0 & 70 \\
\hline 2004 & 10 & 75 & 15 & 0 & 15 & 90 \\
\hline
\end{tabular}

percent to the total contents of these elements in needles (Tab. 3). It testifies that the contents of heavy metals in spruce needles in the Tatrzański National Park is determined mainly by their deposit accumulated in soil for decades.

It should be noted that the concentration of heavy metals deposited on spruce needles is relatively low when compared to the concentration found for other national parks: Magurski, Gorczański and Babiogórski, where these values were several times higher (Staszewski 2002).
The decline in the health status of spruce trees was observed at the permanent plot in the Tatrzański National Park - (mainly in the result of the decrease in number of health trees) between 1998 and 2004, however this stand can be classes as a slightly injured (Tab. 4, 5).

The permanent plot in the Tatrzański National Park is located in the lower deciduous and mixed forests zone. Syntaxonomical position of the phytocoenosis in Abieti-Piceetum association is not doubtful mainly because of location 
Tab. 6: Floral characteristics of permanent plot in the Tatrzanski NP.

\begin{tabular}{|c|c|c|c|c|c|}
\hline \multicolumn{2}{|c|}{ Tree stand } & \multicolumn{4}{|c|}{ Spruce monoculture } \\
\hline \multirow{4}{*}{\multicolumn{2}{|c|}{ Syntaxonomical position }} & \multicolumn{4}{|c|}{ Vaccinio-Piceetea } \\
\hline & & \multicolumn{4}{|c|}{ Vaccinio-Piceetalia } \\
\hline & & \multicolumn{4}{|c|}{ Piceion abietis; Suball:Vaccinio-Abietenion } \\
\hline & & \multicolumn{4}{|c|}{ Abieti-Piceetum } \\
\hline \multirow{2}{*}{ Layer } & \multirow{2}{*}{ Species } & \multicolumn{2}{|c|}{ Frequency } & \multicolumn{2}{|c|}{ Cover range [\%] } \\
\hline & & 2001 & 2006 & 2001 & 2006 \\
\hline A & Piced & 100 & 100 & $5-90$ & $5-90$ \\
\hline $\mathrm{C}$ & Oxalis C & 100 & 100 & $20-90$ & $20-80$ \\
\hline $\mathrm{C}$ & Athyrium & 99 & 100 & $10-70$ & $10-60$ \\
\hline $\mathrm{C}$ & Dryopter & 98 & 99 & $10-60$ & $10-50$ \\
\hline $\mathrm{C}$ & Prenanthe & 92 & 98 & $5-50$ & $10-40$ \\
\hline $\mathrm{C}$ & Rubus & 66 & 78 & $5-50$ & $5-50$ \\
\hline C & Luzula & 43 & 40 & $1-20$ & $1-10$ \\
\hline $\mathrm{C}$ & Sorbusa & 37 & 42 & $1-10$ & $1-10$ \\
\hline $\mathrm{C}$ & Dryopter & 25 & 26 & $5-20$ & $5-20$ \\
\hline $\mathrm{C}$ & Homogy & 20 & 19 & $1-20$ & $5-10$ \\
\hline $\mathrm{C}$ & Petasit & 16 & 15 & $1-20$ & $5-20$ \\
\hline $\mathrm{C}$ & Sambucu & 16 & 21 & $5-20$ & $5-20$ \\
\hline C & Gentiana & 14 & 15 & $1-10$ & $5-10$ \\
\hline C & Stellaria & 14 & 18 & $1-10$ & $1-10$ \\
\hline $\mathrm{C}$ & Galeobdo & 12 & 17 & $1-10$ & $5-10$ \\
\hline C & Polygonatun & 8 & 9 & $1-10$ & $5-10$ \\
\hline $\mathrm{C}$ & Doronicum & 8 & 12 & $5-10$ & $1-10$ \\
\hline $\mathrm{C}$ & Vacciniun & 8 & 8 & $5-10$ & $5-10$ \\
\hline $\mathrm{C}$ & Cardami & 6 & 7 & $5-10$ & $5-10$ \\
\hline $\mathrm{C}$ & Myceli. & 4 & 4 & 10 & $5-10$ \\
\hline $\mathrm{C}$ & Calamagr & 4 & 1 & $1-10$ & 5 \\
\hline $\mathrm{C}$ & Piced & 3 & - & 1 & - \\
\hline $\mathrm{C}$ & Calamagros & 3 & 3 & $1-5$ & $1-5$ \\
\hline $\mathrm{C}$ & Senecion & 3 & 4 & 5 & $1-5$ \\
\hline $\mathrm{C}$ & Luzula & 2 & 4 & 1 & $1-5$ \\
\hline $\mathrm{C}$ & Lonicera & 2 & 3 & $10-20$ & $10-20$ \\
\hline $\mathrm{C}$ & Hieraciun & 2 & 2 & $5-10$ & 10 \\
\hline $\mathrm{C}$ & Carexp & 1 & 1 & 1 & 1 \\
\hline $\mathrm{C}$ & Soldanell & 1 & 1 & 5 & 5 \\
\hline $\mathrm{C}$ & Veratrum & 1 & 2 & 10 & $5-10$ \\
\hline $\mathrm{C}$ & Streptopusc & 1 & - & 5 & - \\
\hline $\mathrm{D}$ & Plagiotheciu & 100 & 100 & $10-100$ & $10-90$ \\
\hline
\end{tabular}


of the plot (steep slope in the stream valley), though the contribution of the species diagnostic for deciduous forests may prove the former fertile habitat, where spruce was planted. The situation is so common in the entire range of the Western Carpathians, that despite saved elements of Querco-Fagetea class, old, spruce forests on stabilized habitat are frequently included into the association. Single-species tree stand reveals high density, up to $90 \%$. Sporadically in small gaps about $5 \%$ of the density was noted. There is no undergrowth in the patch, but the herbs have a structure of two layers. Rubus idaeus, Prenanthes purpurea, Dryopteris filix-mas dominate in higher layer. Sambucus racemosa and juvenile specimens of Sorbus aucuparia are present as well. All species mentioned above revealed an increase of share in the period of 2001-2006. The lower layer is dominated by ferns (Athyrium filixfemina, Dryopteris dilatata). Their participation in

\section{References}

Arndt U., Nobel W., Schweizer B. 1987: Bioindikatoren Moeglichkeiten, Grenzen und neue Erkenntnisse. Ulmer Verlag. Stuttgart, $388 \mathrm{~S}$.

Bytnerowicz, A., Godzik, B., Grodzińska, K., Fraczek, W., Musselman R. C., Manning W. J., Badea O., Popescu F., Fleischer P. 2004: Ambient ozone in forests of the Central and Eastern European mountains. Environmental Pollution, 130: 5-16.

Cape, J. N., Paterson, I. S., Wolfenden, J. 1989: Regional Variation in surface properties of Norway spruce and Scots pine needles in relation to forest decline. Environmental Pollution, 58: 325-342.

Europe's Environment, 1995: Dobris report, D. STANNERS AND P. Bourdeau (eds.). European Environment Agency Task Force (European Commission: DG XI and Phare), Copenhagen, 676 pp.

GoDzIK, B. 2006: Tropospheric ozone measurements in the Tatra Mountains and its effects on plants. In: G. ArAPIS, N. Goncharova, P. BAVEye (eds.) Ecotoxicology, Ecological Risk Assessment and Multiple Stressors. NATO Security through Science Series - C: Environmental Security, Series IV: Earth and Environmental Series - Vol. 6. Springer, Netherlands, 325-336.

GUS 2006: Główny Urzad Statystyczny. Warszawa, $77 \mathrm{~s}$. the herb layer inconsiderably increased, nevertheless they determined the characteristic physiognomy of the phytocoenosis. The moss layer is formed mostly irregular. It reached a cover of about $100 \%$ in some squares, and barely about $10 \%$ in the others. Distinctive traits of the plot is presence of the endemic to the Western Carpathians species Soldanella carpatica (Tab. 6).

\section{Conclusions}

Analysis of air pollution level in the investigation area proved exceeded ozone concentration to be the factor responsible for the deterioration of the health status of spruce stand in the Tatrzański National Park. Generally, the investigation showed a stability of the forest ecosystem in the last decade. It can loom large the presence of carcinogenic PAHs in the air of the park, but this aspect of hazard needs require further investigation.

Heinrichs, H., Mayer, R. 1980: The Role of Forest vegetation in the Biogeochemical Cycle of Heavy Metals. Journal of Environmental Quality, 9 (1): 111-118.

ICP-FoREST, 1998: Manual on methods and criteria for harmonized sampling, assessment, monitoring and analysis of the effects of air pollution on forests. Tech. rep., Federal Research Centre for Forestry and Forestry Products (BFH). Hamburg, Germany, edited in May 1998 by the programme Coordinating Centra, 177 pp.

Jol, A., Kielland, G. (eds.) 1997: Air pollution in Europe 1997. EEA Environmental Monography, No. 4. EEA. Copenhagen, 107 pp.

Jones, K. C., Grimmer, G., Jacob, J., Johnston, A. E. 1989: Changes in polycyclic aromatic hydrocarbon content of wheat grain and pasture grassland over the last century from one site in the UK. Science of the Total Environment, 78: 117-130.

Jones, K. C., SAnder, S. G., Wild, S. R., Burnett, V. B., Johnston, A. E. 1992: Evidence for the decline in PCBs and PAHs in rural UK vegetation and air. Nature, 356: 137-140.

Journal of LaWs of 2002, No. 87, ITEM 796: Regulation of the Minister of Environment on admissible levels of some substances in the air, on alarm levels of some substances in the air, and on tolerance margins for admissible levels of some substances. $6 \mathrm{pp}$. 
Kabata-Pendias, A., Pendias, H. 1992: Trace elements in soils and plants. Boca Raton: CRC Press, 365 pp.

Matuszkiewicz, W. 2001: Przewodnik do oznaczania zbiorowisk roślinnych Polski. Vademecum Geobotanicum 3. FALIŃsKi B. [ed.]. Wyd. PWN, Warszawa. 537 s.

Mill, W., Pecka, T., Schlama, A. 2009: National Focal Centre Report - Poland, In. HettelINGH, J. P., Slootweg, J., Posch, M. (eds.) 2008: Critical Load, dynamic Modelling and Impact Assessment in Europe, CCE Status Report, PBL, Bilthoven, The Netherlands. 171-175.

Mirek, Z., PięKoś-Mirkowa, H., Zając, A., Zając, M. 2002: Flowering plants and Pteridiophytes of Poland. A checklist. Instytut Botaniki PAN. Kraków, 441 pp.

Ochyra, R., Żarnowiec, J., Bednarek-Ochyra, H. 2003: Census catalogue of Polish mosses. Polish Academy of Sciences, Institute of Botany, Kraków, 372 pp.

Programme Coordinating Centres (PCC) (eds.), 1994: UN-ECE Convention on Long-Range Transboundary Air Pollution - International Cooperative Programme on Assessment and Monitoring of Air Pollution Effects on Forests: Manual on methods and criteria for harmonized sampling, assessment, monitoring and analysis of the effects of air pollution on forests. Hamburg, Prague, Programme Coordinating Centres West and East. 177 pp.

RIEDERER, M. 1990: Estimating partitioning and transport of organic chemicals in the foliage/atmosphere system: discussion of a fugacity-based model. Environmental Science and Technology, 24: 829-837.

StaszewsKi T. 2002: Ocena efektów realizacji Polityki Ekologicznej Państwa w zakresie redukcji emisji metali cię̇kich na podstawie ich akumulacji w ekosystemach drzewostanów iglastych ze szczególnym uwzględnieniem terenów specjalnie chronionych-parki narodowe. Raport Instytutu Ekologii Terenów Uprzemysłowionych. Katowice, $75 \mathrm{~s}$.

StAszewsKi, T. 2004: Reakcja drzewostanów swierkowych na depozycie zanieczyszczeń powietrza. Wydawnictwo Naukowe Uniwersytetu Śląskiego, $168 \mathrm{~s}$.

SzAreK, G., BraniewsKi, S. 1996: Metale ciężkie w opadzie ściółki lasu mieszanego zlewni potoku Ratanica. Sylwan, 4: 53-61.

Turner, R. S., Johnson, A. H., Wang, D. 1985: Biogeochemistry of lead in McDonalds Branch Watershed, New Jersey Pine Barrens. Journal of Environmental Quality, 14: 305-314.

UN-ECE 1998: Forest Condition in Europe. Technical Report. UN-ECE and EC, Geneva and Brussels, 305-314.

Wild, S. R., Berrow, M. L., McGrath, S. P., Jones, K. C. 1992: Polynuclear aromatic hydrocarbons in crops from long-term field experiments amended with sewage sludge. Environmental Pollution, 76: 25-32.

Wild, S. R., Jones, K. C. 1991: Studies on the polynuclear aromatic hydrocarbon content of carrots (Daucus carota). Chemosphere, 23: 243-251.

Wild, S. R., Jones, K. C. 1992: Polynuclear aromatic hydrocarbon uptake by carrots grown in sludge - amended soil. Journal of Environmental Quality, 21: 217-225.

ZötтL, H. W. 1985: Heavy metal levels and cycling in forest ecosystems. Experiments, 41: 1104-1113. 
